\title{
GRANT ME JUSTICE! READING THE CHRONICLE OF THE ORDINATION OF WOMEN IN THE MCSA AS THE MAKING OF A PATRONAGE MINISTRY
}

\section{Obusitswe Tiroyabone-A-Sedupelela}

University of South Africa

sitswe@gmail.com

\section{ABSTRACT}

In 2016 the Methodist Church of Southern Africa (MCSA) celebrates 40 years of the ordination of women, which signifies a milestone in the ministry. While this calls for celebration, it is also important that we lament the challenges women ministers are still facing in the church. The chronicle of how the church came to ordain women as ministers in the MCSA cites tensions and debates as well as theological arguments for and against the ordination of women. This paper reads this chronicle with a hermeneutic of suspicion. The paper holds that the decision of the church to ordain women has not translated to women being ordained ministers like men within the church, but rather that the decision created a patronage system within the ministry where male ministers (and their wives) are patrons and female ministers their clients. The woman minister in the MCSA joins the woman in the Luke narrative who continues to go to the judge (the MCSA) and laments: "Grant me justice!"

Keywords: Methodist Church of Southern Africa (MCSA); justice; women; ordination; patronage ministry

\section{INTRODUCTION}

This paper carries on the struggle of the woman in the narrative in Luke 18:1-8 who goes to the unjust judge repeatedly and laments: "Grant me justice!" This plea or lamentation is the focus of my paper, concentrating on the plight of women ministers in the MCSA and the MCSA's refusal to grant her justice in good faith. I will begin

\section{UNISA}


by presenting a concise chronicle of the ordination of women in the MCSA and then present a brief analysis of the narrative in Luke 18:1-8 in relation to the plight of women. I will then unpack my analysis of the ministry of women as the creation of a patronage ministry wherein male ordained ministers are to act as patrons and women ministers as clients. Lastly, I will engage in a criticism of the chronicle of the ordination of women as a postcolonial reader.

\section{THE ORDINATION OF WOMEN IN THE MCSA}

The year 2016 marks 40 years since the MCSA began to ordain women. This is a historic year which celebrates the great progress that the church has made towards ordaining women. Yet it also calls for introspection as a church to evaluate how we treat women as ministers and what space they occupy as agents of God's mission in the life of the church. Let us begin by tracing the history of the ordination of women in the Methodist Church of Southern Africa.

According to Mkhwanazi and Kgatla, ${ }^{1}$ the acceptance of women in the ministry of the MCSA started with the introduction of deaconesses. Deaconesses were introduced long ago in the MCSA, before 1963, and most of them were white deaconesses and were trained overseas. ${ }^{2}$ Mkhwanazi and Kgatla ${ }^{3}$ further note that women who felt called to ministry were given positions as deaconesses. This practice, according to Mkhwanazi and Kgatla, ${ }^{4}$ followed the same understanding as that of the Methodist Church of England, where women who felt called could become a candidate for the ministry. They are exempt from writing the written examination to become candidates of ministry; they are only allowed to follow and fulfil the rules and regulations which apply to male candidates. ${ }^{5}$ Probation proceeds as it is stipulated in the rules of the church, but the female candidate can be on probation for another three years before she may be ordained for ministry. ${ }^{6}$ Constance M. Oosthuizen was the first woman deaconess to be ordained in the ministry of Word and Sacrament in the MCSA in 1976 and at that time, the warden of the Deaconess Order had left South Africa for Canada. ${ }^{7}$ The Conference did not hesitate to appoint Oosthuizen as a successor and in the following year, Oosthuizen was appointed to the Lower South Coast Circuit (in Port Shepstone) where she led an uninterrupted

1 Fanie S. Mkhwanazi and Tias Kgatla, "The Place of Women Ministers in the Mission of the Methodist Church of Southern Africa" in Studia Historiae Ecclestiasticae, Volume 41, Number 2, $2015,185$.

2 Mkhwanazi and Kgatla, "The Place of Women Ministers", 186.

3 Mkhwanazi and Kgatla, "The Place of Women Ministers", 186.

$4 \quad$ Mkhwanazi and Kgatla, "The Place of Women Ministers", 186.

5 Mkhwanazi and Kgatla, "The Place of Women Ministers", 186.

6 Mkhwanazi and Kgatla, "The Place of Women Ministers", 186.

7 Mkhwanazi and Kgatla, "The Place of Women Ministers", 186. 
ministry in that Circuit from 1977 until her retirement in $1997 .{ }^{8}$ In the plight of women asking to be ordained Oosthuizen was followed by Dorothy Spink, who was a candidate while she was a probationer deaconess and was ordained in 1978. ${ }^{9}$ This Order contributed to the first black woman ordained in the South African Methodist ministry in the person of Nikiwe Mavis Mbilini, who was ordained in $1985 .{ }^{10}$

\section{GRANT ME JUSTICE!}

The parable in Luke 18:1-8 tells of a woman who lived in a certain city. In this city there was a judge who neither feared God nor had respect for people. The woman kept on going to him time and again and lamented: "Grant me justice against my opponent." ${ }^{11}$ However, she received no justice from the judge. In the end the judge says to himself: "Even though I do not fear God nor have respect for people, let me grant this woman what she wants so that she stops bothering me."12 It is my contention that the MCSA has taken the route of this unjust judge. The MCSA has accepted women in the ordained ministry to silence them because they were making too much noise. Today, when women ministers ask for fair and just treatment by the church (the judge) against the unjust oppression received from their male counterparts (the opponent), the MCSA just gives them what they want not because they are genuine requests in their reckoning, but to silence them.

The ordinations of these women (Oosthuizen and Mbilini) saw the start of many difficulties as more women offered themselves for the ministry but were turned down. Their training at the seminary was the same as that of their male counterparts, but they were treated as second-class citizens in the ministry. For example, when the seminary attached women to nearby churches, they were not allowed to preach but had to run Sunday Schools and participate in church choirs. One may think of a seed that is being planted without having made the soil ready for it. Yes, the seed is there that there should be women ministers in the church, but how has the soil (the church) been made ready for the seed? What good is it to plant women ministers in congregations when the congregations themselves are not ready to receive them? Why should the church continue to accept women into the ordained ministry when she doesn't make space for women? The General Secretary reports that only four per cent of superintendents in the MCSA are women. ${ }^{13}$ As we celebrate 40 years of the ordination of women in our church, we should be careful to remember that since 1976 only one woman minister has served as bishop and only one woman currently

8 Mkhwanazi and Kgatla, "The Place of Women Ministers", 186.

9 Mkhwanazi and Kgatla, "The Place of Women Ministers", 186.

10 Mkhwanazi and Kgatla, "The Place of Women Ministers", 186.

11 Luke 18: 3 English Standard Version.

12 Luke 18: 4-5 English Standard Version.

13 Methodist Church of Southern Africa, The Yearbook and Directory (Cape Town: Methodist Publishing House, 2016), 21. 
serves as general secretary - and we are yet to have a woman presiding bishop. More alarming is the fact that in many sectors of our church women are not accepted to serve in stations. The seed is being planted, yet the soil has not been made ready for it. The persistence of the woman in the Lukan narrative can be seen in the plight of women ministers in the MCSA who continue to lament "grant me justice!" but the MCSA ignores her voice and pretends her request is not reasonable. Instead of granting her request in good faith, the MCSA granted women ministers the right to be ordained just to silence them and subdue them to a patronage ministry.

\section{THE ORDINATION OF WOMEN AS A PATRONAGE MINISTRY}

It is my contention that the church, instead of creating a safe space for women to be ordained ministers, has rather created a patronage ministry where male ministers act as patrons and female ministers as their clients. The form of ministry for male and female ministers in the MCSA is not an equal one. There seems to be an unwritten law that says male ministers are more superior and deserve more respect and more recognition. The failure of the church to create a safe space for female ministers resulted in the creation of this patronage ministry. The church has not done enough to address the patriarchal mind-sets of people and instil in them the notion that all ministers, whether male or female, are equal.

Patron-client systems are relations in society based on generalised reciprocity between social un-equals in which a lower status person in need, called a client, has his needs met by having resource for favours to a higher-status, well situated person called a patron. ${ }^{14}$ When granted a favour, the client promises to pay back the patron whenever and however the patron decides. As the patron grants the favour, they in turn promise to be open for further requests at other times. ${ }^{15}$ When entering a patronclient agreement, the client relates to the patron as to a superior and more powerful kinsman, while the patron ensures that his clients are taken care of as he would his dependants. ${ }^{16}$ Garnsey and Saller ${ }^{17}$ note that one of the main motivations for this system is that one of the things a Roman citizen prided himself in is their place in society and having a position in the social hierarchy, even extending out from his household. Romans were obligated to and could expect support from their families, kinsmen and dependants both inside and outside the household, friends, patrons,

14 Bruce J. Malina and John J. Pilch, Social Commentary on the Book of Acts (Minneapolis: Fortress Press, 2008), 227.

15 Malina and Pilch, "Social Commentary on Acts", 227

16 Malina and Pilch, "Social Commentary on Acts", 227

17 Garnsey, Peter and Saller, Richard, "Patronal Power Relations" in Paul and Empire: Religion and Power in Roman Imperial Society edited by Richard A. Horsley (Harrisburg: Trinity Press International, 1997), 96. 
protégés and clients. ${ }^{18}$ The emperor of Rome acted as a patron of many clients throughout the Roman territories. ${ }^{19}$ The Roman provinces were led by governors who together with the provinces' elites were the clients of the Roman emperor. ${ }^{20}$ The emperor, being the powerful and in control of the Roman colonies, provided certain securities to his clients which reciprocated by being his obedient subjects. ${ }^{21}$ The emperor gave benefits to the Roman people and was regarded as being a good patron. The people returned the favours with respect and loyalty. ${ }^{22}$

The system of patronage did not exist to provide social and economic securities for clients, as much as it existed to secure the pride and status of the patron. The system itself was created to be an unequal system and retain the lesser in rank at the lower level and the more powerful in a higher position. The chronicle of the road to the ordination of women suggests a pyramid structure of patronage that places a male ordained minister at the pinnacle of the structure and women at the feet of the structure. It is my contention that when in $1890 \mathrm{Rev}$. Applebe ordained Sister Theresa as a deaconess he was not creating space for her as a minister, but he was creating a patronage ministry where as a deaconess Sister Theresa would always depend on a male ordained minister for ministerial benefits. A deaconess would always have to wait for her patron male ordained minister to come and administer the Sacraments to her congregation. She may have been ordained, but just as in the patronage system not to an equal status as her male counterparts. I contend that this ministerial patronage system continued when in 1976 the church ordained Constance Oosthuizen as a minister. She entered into a patron-client system with her male counterparts where she remained in need of their assistance. She was the only female minister and as such faced being an outcast in a boys' club. The church in its inability to prepare the soil for the seed created the patronage ministry where Oosthuizen still needed the male ordained ministers to welcome her into the boys' club, orientate her into the boys' club and prepare the people for her to minister to.

This patronage ministry continued when Nikiwe Mbilini was also ordained. In a patron-client relationship the patron is always more powerful than the client. As much as the patron provides services and favours to the client, they will ensure that they keep the power to themselves. The leadership of the church has to this point been reserved for the patron male ordained ministers. Women like Mbilini have not been given a chance to lead - even at circuit level. I draw attention to two of our most powerful organisations in the black section of the church: the Young Men's Guild (YMG) and the Women's Manyano (WM). According to the constitution of the

18 Garnsey and Saller, "Patronal Power Relations", 96.

19 Garnsey and Saller, "Patronal Power Relations", 96.

20 Garnsey and Saller, "Patronal Power Relations", 96.

21 Brigitte Kahl, Galatians Re-Imagined: Reading with the Eyes of the Vanquished (Minneapolis: Fortress Press, 2010), 43-44.

Garnsey and Saller, "Patronal Power Relations", 97. 
YMG "only men who are full members of the MCSA, including male ordained and student ministers shall be received into full membership of the YMG. The Circuit President shall be the Superintendent Minister of the Circuit provided that he is a member of the YMG". ${ }^{23}$

The emphasis on men segregates women and discards them from leading the organisation. The implication of this clause of the YMG constitution is that where a female minister leads a congregation, she must always seek the services of her patron male ordained minister to come and lead the YMG for her. Even in circuits where superintendents are females and there are no male ministers, leadership will be borrowed from an adjacent circuit. This patronage ministry exists because for 40 years the church has not observed the changing patterns of society and as such has not created a safe space for women to practise all forms of ministry according to their calling. I contend that the church has reserved certain aspects of ministry for men. Even when it comes to women, a female minister must still depend on her patron male ordained minister's wife! According to the Women's Manyano Circuit Organisation: ${ }^{24}$

...the Manyano in each Circuit shall be managed by a Circuit Executive Committee consisting of the Circuit President, who shall be the wife of the Superintendent Minister, provided that she is a member of the Manyano. If the wife of a Superintendent Minister is not a member of the Manyano, the wife of the most senior ordained and active Minister in the Circuit who is a member of the Manyano may be the Circuit President. If the most senior ordained and active Minister in the Circuit is a Woman Minister who is a member of the Manyano 'she may be' the Circuit President. In the absence of the above, the wife of the most senior student Minister who is a member of the Manyano may be the Circuit President.

It is noteworthy that the constitution (written by a patron male ordained minister) does not begin by identifying a female minister as a leader of the organisation, but begins with the wife of the patron and considers later that a female minister "may" be a leader. With the wife of the patron male ordained minister it says "shall be", but with the client female ordained minister it says "may be". The constitution of the church itself preserves the power within the hands of the patron male ordained minister. The seed is ready, but when will the soil be ready for the seed?

Ordination in the MCSA is recognition that man or woman has received the grace of God which is affirmed by the laying of hands of human beings. The woman or man so ordained is set apart for the ministry of Word and Sacrament as well as pastoral oversight of the people of God. ${ }^{25}$ However, as I indicated in my motivation above, I have observed that there are hindrances when it comes to the equality of

23 Methodist Church of Southern Africa Constitutions of the MCSA (Cape Town: Methodist Publishing House, 2009), 93-94.

24 MCSA "Constitutions", 87.

25 Methodist Church of Southern Africa, The Laws and Disciplines of the Methodist Church of Southern Africa: 11th Edition (Cape Town: Methodist Publishing House, 2007), 28. 
ordained men and women as depicted by the ordination. Ordained women in the MCSA are struggling to express their God given talents and skills under these observed difficulties such as patriarchy, sexism, gender, culture and the Bible. Ordained women in the MCSA are regarded as incapable of occupying the most senior positions of the church because church structures, standards and norms are for the physically strong. Women cannot measure up to the role of sacred masculinity and they remain third class according to their gender; this ideology that permeates in the MCSA perpetuates the form of patronage ministry that women have had to be subjected to. The MCSA seems to be comfortable with this patronage ministry, evidenced by its reluctance to change the way things are. This patronage ministry continues and the woman minister continues to lament: "Grant me justice!"

\section{GRANT ME JUSTICE!}

It is the contention of this paper that women ministers in the MCSA have for 40 years been made to partake in a patronage ministry. The woman in the Lukan narrative displays a calibre of persistence. She goes to the judge, gets turned down and goes back without any justice. And then she gets up again the following day (I would imagine) and then goes back to the same judge who wouldn't give her justice and still laments: "Grant me justice!" How strong was her faith in the justice system! How strong were the faiths of Constance Oosthuizen; Nikiwe Mbilini; Libuseng Lebaka-Ketshabile; and Purity Malinga? How strong are the faiths of the young women who are still to this day offering for the ministry despite knowing that they will enter into a patronage ministry where, as clients they will have to pay allegiance to patrons? For 40 years women ministers in the MCSA have been lamenting, but the MCSA will not grant them justice.

It is important that as a postcolonial optic I bring some questions as I read the chronicle of the ordination of women in the MCSA. The first question I ask is: How are the readers reading the chronicle - as colonisers, the colonised or collaborators? ${ }^{26}$ As presented to us with the MCSA celebrating 40 years since the first woman was ordained, the chronicle suggests that the MCSA has much to celebrate as they led many a church in Southern Africa in the ordination of women. The chronicle is presented by hegemonic structures of the MCSA who assume the position of being better than other churches by being one of the earliest churches to ordain women in Southern Africa. However, as collaborators of the colonisation and the oppression of women in Southern Africa, the MCSA's "hegemonic" structures downplay the fact that women ministers have been forced to be clients of their male counterparts in the ministry along with their wives. As collaborators of the colonisation of women, the

26 These questions are proposed by postcolonial interpreter, Musa Dube, who argues that they are to be posed when reading a text in the postcolonial era. As I read this chronicle that was crafted in the colonial and neo-colonial frameworks, the questions are important and need to be posed. 
MCSA has had 40 years to emancipate women ministers, but their male domination agenda has led them to keep power within their male hands and would rather distribute it to their wives than their female counterparts. The chronicle of the ordination of women in the MCSA emulates Rev. Purity Malinga as the first woman to be bishop in the MCSA, yet the chronicle (written by male ordained patron ministers) does not reflect or even interrogate the fact that, as a woman, Rev. Malinga had to be exposed to a men's club and sit in a bishops' meeting that was comprised of 13 other men and she was the only woman. Emphasising her appointment without recognising the difficulty she was forced to go through as the only woman bishop, is characteristic of collaborators of the colonisation of women.

I contend that the chronicle of the ordination of women in the MCSA is a project of the collaborators of the colonisation of women in the church. The woman who first said "grant me justice!" more than 40 years ago, is not different from the woman who laments today "grant me justice!" because she has to dress like an oppressed woman in a rural village and behave and act like a man. When she ascends the pulpit a man is expected from her; when she chairs a meeting her emotions must portray a man; when she does pastoral counselling and care she has to advise like a man and she must uphold the male patriarchal domination of society. The cry and struggle continues today for the woman minister as she daily goes to the judge and says "grant me justice!" because the MCSA does not allow her to be lesbian and still minister. As collaborators of the colonisation of women the MCSA still expects and waits with eager anticipation when the woman minister will be married to a man because as a client in the patronage ministry she is not allowed to be who she is or who she wants to be! She goes daily to the MCSA and says please "grant me justice!", but because the MCSA is led and dominated by men, her cry is ignored and she is just given a small piece of the pie to cut her teeth on.

The next question I use to approach this chronicle is: On which side of the text am I journeying as a reader? As a postcolonial optic I choose the side of the oppressed; I choose to journey with the women ministers who have been marginalised for 40 years and made to think and believe that they are inadequate and can only serve best as the assistants of men. I choose to journey with Constance Ooosthuizen and Nikiwe Mbilini who had to be told that they can only be deacons and the role of a minister (as emulated higher in the order of ordination) is reserved for men. I choose to journey with Libuseng Lebaka-Ketshabile who had to endure the pain of not being stationed because she is a woman. As I read this chronicle I journey with Lebaka-Ketshabile because for the MCSA, led by male ordained patron ministers, her stationing depended on where her husband would be stationed and refused to recognise that she is a woman of note herself, independent of her husband. As I read this 40 year chronicle of the ordination of women I choose to journey with Purity Malinga who for nine years had to put up with male chauvinism meeting after meeting and to some extent had to preserve systems and structures which were in 
favour of men and neglect her sisters in the struggle because the patronage ministry in which she is in, did not give her space to breathe. I choose to journey with the young women who today have to align themselves with the standing societal patterns of marriage and family life because if they dare whisper an alternative life, they will face discontinuance.

Another question for the postcolonial reader as I engage the chronicle of the ordination of women in the MCSA is: Does this chronicle have a clear stance against the political imperialism of its time? The answer is no! The narration of the events leading to the ordination of women shows the church's lack of affirmation of the ordination of women, in fact the church bended with the societal imperialism of its time that sought to oppress and subordinate women. The MCSA was not clear, but had to be pushed by the persistence of the women who wanted to be ordained as they lamented: "Grant me justice!" This leads me to my last question: Does this chronicle employ gender and divine representations to construct relationships of subordination and domination? Yes! The chronicle indicates that women ministers were never given a fair chance as equals to their male counterparts, but were given an assistive role. When deciding on leadership the MCSA would rather choose a man to be bishop and a woman to be secretary of synod - as if women are only good to be scribes. The unspoken language of the MCSA subordinates women and gives them a secondary role in the ministry. This unspoken language constructs a relationship of subordination and domination between male ordained ministers and female ordained ministry and constructs a patronage ministry.

\section{CONCLUSION}

I have indicated at the beginning of this paper that my aim is to read the chronicle of the ordination of women as the making of a patronage ministry: re-reading the history and critiquing the reluctance of the MCSA to grant women justice. It is the conclusion of this paper that the MCSA has for 40 years acted like the unjust judge in the Lukan narrative who granted the woman justice just to silence her. It is not enough that she just be given what she wants only to silence her. The MCSA must be intentional in promoting an equal ministry for men and women; the MCSA must do more to educate its members on the role and importance of women in the ministry and must act like a just judge. Fiorenza argues that upon baptism into the Christian faith, as evidenced by the baptismal formula of Galatians 3:28, men had to relinquish their power over women; masters over their slaves; patrons over their clients. ${ }^{27}$ After 40 years of subordination and the perpetual cry of women ministers "grant me justice!" the time has come for male ordained ministers acting as patrons

27 Elizabeth Schussler Fiorenza, "The Praxis of Coequal Discipleship" in Paul and Empire: Religion and Power in Roman Imperial Society edited by Richard A. Horsley (Harrisburg: Trinity Press International, 1997), 231. 
of the ministry to relinquish their power over women ministers and foster a new ministry: an equal ministry. In the meantime, this courageous and strong faithful woman who is a minister continues to wake up daily; she dresses like a man; talks like a man (because this is a man's club and the only way to get in) and laments: "Grant me justice!" Her waiting must stop now; her bleeding must come to an end; her pain must now be soothed. 40 years of the same lament is too much, it is time for the male ordained patron minister to relinquish his power and in good faith grant the woman client minister the justice she has wept for.

\section{REFERENCES}

Bruce J. Malina, and John J. Pilch. Social Commentary on the Book of Acts, 227. Minneapolis: Fortress Press, 2008.

Fiorenza, Elizabeth Schussler. "The Praxis of Coequal Discipleship." In Paul and Empire: Religion and Power in Roman Imperial Society, 231. Edited by Richard A. Horsley. Harrisburg: Trinity Press International, 1997.

Garnsey, Peter, and Richard Saller. "Patronal Power Relations." In Paul and Empire: Religion and Power in Roman Imperial Society, 96. Edited by Richard A. Horsley. Harrisburg: Trinity Press International, 1997.

Kahl, Brigitte. Galatians Re-Imagined: Reading with the Eyes of the Vanquished, 43-4. Minneapolis: Fortress Press, 2010.

Methodist Church of Southern Africa. The Laws and Disciplines of the Methodist Church of Southern Africa. 11th edition, 28. Cape Town: Methodist Publishing House, 2007.

Methodist Church of Southern Africa. Constitutions of the MCSA, 93-4. Cape Town: Methodist Publishing House, 2009.

Methodist Church of Southern Africa. The Yearbook and Directory, 21. Cape Town: Methodist Publishing House, 2016.

Mkhwanazi, Fanie S., and Tias Kgatla. "The Place of Women Ministers in the Mission of the Methodist Church of Southern Africa." Studia Historiae Ecclestiasticae, 41(2): 185, 2015. 